\title{
Metode Diskusi dalam Pembelajaran Menentukan Unsur Intrinsik Tema di Sekolah Menengah Atas
}

\section{Discussion Methods in Learning Determine Intrinsic Elements of Themes in Senior High Schools}

\author{
Gita Rahayu 1
}

Artikel diterima editor tanggal 27-02-2021, disetujui untuk dipublikasikan tanggal 27-05-2021

Doi: $x x x x x-x x x x x$

\begin{abstract}
Abstrak
Kemampuan peserta didik dalam pembelajaran menentukan unsur tema cerpen masih rendah. Oleh karena itu, pelaksanaan pembelajaran memerlukan strategi yang efektif dan efisien. Tujuan yang terdapat dalam penelitian ini yaitu. 1) Menjelaskan kemampuan peserta didik dalam menentukan unsur tema cerpen Juru Masak karya Muhammad Damhuri di Kelas XI SMA Negeri 1 Maja sebelum pembelajaran menggunakan metode diskusi? 2) Menjelaskan kemampuan peserta didik dalam menentukan unsur tema cerpen Juru Masak karya Muhammad Damhuri di Kelas XI SMA Negeri 1 Maja setelah pembelajaran dengan menggunakan metode diskusi? 3) Menjelaskan efektivitas penggunaan metode diskusi dalam pembelajaran menentukan unsur tema cerpen Juru Masak karya Muhammad Damhuri di Kelas XI SMA Negeri 1 Maja. Metode penelitian yang digunakan dalam penelitian ini yaitu metode deskriptif. Sedangkan teknik pengumpulan data yang digunakan ialah teknik kepustakaan dan teknik tes (pretest dan posttest). Berdasarkan hasil pengolahan data dan pembahasan menunjukkan perolehan nilai rata-rata pretest sebesar 71 atau $71 \%$, sedangkan perolehan nilai rata-rata posttest sebesar 79,2 atau $79,2 \%$. Artinya kemampuan peserta didik mengalami peningkatan nilai rata-rata sebesar 8,2 atau 8,2\% setelah menggunakan metode diskusi. Berdasarkan penghitungan menggunakan rumus korelasi product moment menunjukkan nilai korelasi sebesar 0,760 atau berdasarkan pedoman pemberian interpretasi koefisien korelasi data menunjukkan korelasi yang tinggi.
\end{abstract}

Kata kunci: Efektivitas, Metode diskusi, Pembelajaran, Cerpen.

\begin{abstract}
The ability of students in learning to determine the elements of the short story theme is still low. Therefore, the implementation of learning requires an effective and efficient strategy. The objectives contained in this study are. 1) Explain the ability of students in determining the elements of the theme of the short story Chef Muhammad Damhuri in Class XI SMA Negeri 1 Maja before learning using the
\end{abstract}

\footnotetext{
${ }^{1}$ Gita Rahayu, SMAN 1 Sumberjaya, gitarahayu0808@gmail.com
} 
discussion method? 2) Explain the ability of students in determining the elements of the theme of the short story cook by Muhammad Damhuri in Class XI SMA Negeri 1 Maja after learning using the discussion method? 3) Explain the effectiveness of the use of the discussion method in learning to determine the theme elements of the short story Chef Muhammad Damhuri in Class XI SMA Negeri 1 Maja. The research method used in this research is the descriptive method. While the data collection techniques used were literature techniques and test techniques (pretest and posttest). Based on the results of data processing and discussion, the average pretest score was 71 or $71 \%$, while the posttest average score was 79.2 or $79.2 \%$. This means that the ability of students has increased in average value by 8.2 or $8.2 \%$ after using the discussion method. Based on calculations using the productmoment correlation formula, it shows a correlation value of 0.760 , or based on the guidelines for providing interpretation, the data correlation coefficient shows a high correlation.

Keywords: Effectiveness, discussion methods, learning, short stories

\section{Pendahuluan}

Pembelajaran pada dasarnya adalah proses transfer ilmu pengetahuan dan kemampuan baru. Usaha meningkatkan keberhasilan dalam pembelajaran, merupakan tantangan yang selalu dihadapi oleh setiap guru. Hal ini selaras dengan pernyataan bahwa belajar adalah keseluruhan proses yang dilakukan dalam memperoleh perubahan tingkah laku hasil interaksi dengan lingkungan pembelajar tersebut (Daryanto, 2009; Saman et al., 2015). Upaya Pemilihan dan penggunaan strategi, metode, serta teknik pembelajaran yang dapat membantu siswa untuk belajar lebih baik sangat perlu dimiliki guru. Pada akhirnya proses keberhasilan pembelajaran, yaitu bagaimana seorang guru memberikan pembelajaran yang memungkinkan terjadinya proses belajar yang efektif sehingga dapat mencapai hasil yang sesuai dengan tujuan pembelajaran.

Proses belajar mengajar di SMA khususnya dalam pembelajaran menentukan unsur tema dalam cerpen belum sepenuhnya dapat dikuasai. Hal ini terjadi dikarenakan beberapa faktor, diantaranya; siswa belum mampu memahami isi cerpen dengan baik, penyebabnya siswa belum mengerti atau memahami secara baik unsur intrinsik di dalam cerpen tersebut, baik yang secara tersirat maupun tersurat. Hal ini mengakibatkan hasil yang diharapkan jauh dari standar harapan, siswa pun menjadi bosan akan pembelajaran menganalisis salah satu unsur instrinsik ini (Made et al., 2013).

Seorang guru dalam memilih dan menggunakan metode pembelajaran khususnya mengenai pembelajaran mengapresiasi sastra yang digunakan dalam proses belajar mengajar. Kegagalan pembelajaran membaca pemahaman cerpen pada siswa SMA cukup besar. Gambarannya antara lain sebagai berikut, yaitu: (1) siswa belum mampu mendeskripsikan unsur intrinsik yang tersirat maupun tersurat dari cerpen yang dibacanya, (2) siswa belum memahami cara menentukan tema dari cerpen yang dibacanya, (3) siswa kurang berminat untuk membaca cerpen, dan (4) Siswa belum terbiasa mengapresiasi cerpen yang dibacanya.

Jenis metode pembelajaran sangat beraneka ragam, menurut Sanjaya (2012) yaitu; metode ceramah, metode demonstrasi, metode diskusi, dan metode simulasi. Sementara itu menurut Sumiati dan Arsa (2011) yaitu; metode ceramah, metode simulasi, metode demonstrasi dan eksperimen, metode inquiry dan discovery, metode latihan dan praktik.

Terkait dengan pembelajaran menentukan unsur tema cerpen, metode diskusi dapat dijadikan sebagai salah satu pilihan yang tepat dan efektif. Menurut Sanjaya (2012) metode diskusi memiliki kelebihan: (1) merangsang siswa untuk lebih kreatif dalam mengambangkan ide atau gagasan, (2) melatih pembiasaan diri untuk bertukar pikiran dalam pemecahan masalah, (3) sebagai ajang latihan mengemukakan pendapat, serta melatih jiwa sosial untuk menghargai pendapat orang lain.

Berdasarkan pemaparan latar belakang di atas penulis tertarik untuk melakukan penelitian tindakan kelas dengan judul Efektivitas Penggunaan Metode Diskusi dalam Pembelajaran 


\section{JGI: JURNAL GURU INDONESIA}

2021, 1(1), hlm. $27-33$

https://jurnal.ppjb-sip.org/index.php/igi/index

E-ISSN: XXXX-XXXX | DOI: xxxxx-xxxxx

Menentukan Unsur Intrinsik Tema Cerpen Juru Masak Karya Muhammad Damhuri Kelas XI Sekolah Menengah Atas Negeri 1 Maja..

\section{Metode penelitian}

Metode yang digunakan dalam penelitian ini adalah metode deskriptif. Alasan penulis dalam penelitian ini menggunakan metode deskriptif adalah penulis ingin mendeskripsikan suatu permasalahan dengan apa adanya. Sesuai dengan pernyataan Sudjana \& Ibrahim (2001) metode penelitian deskriptif merupakan penelitian yang menjelaskan atau menggambarkan kejadian, gejala, fenomena yang terjadi saat ini. Dapat dikatakan penelitian deskriptif memiliki pusat perhatian masalah-masalah yang terjadi saat penelitian berlangsung.

Populasi \& sampel

Dalam penelitian ini populasi yang digunakan sebagai sumber data yaitu kelas XI SMA Negeri 1 Maja dengan jumlah siswa 216 orang dan 8 kelas, seperti pada tabel di bawah ini. Penelitian ini menggunakan simple random sampling atau sampel acak (Sugiyono, 2010). Sampel yang ditetapkan adalah siswa kelas XI MIPA 1 dengan jumlah siswa 26 orang yang telah ditentukan sebelumnya menggunakan teknik sampel acak.

Teknik Pengumpulan Data

Data dalam penelitian ini adalah nilai sebelum pembelajaran dan setelah pembelajaran menentukan unsur tema cerpen Juru Masak karya Muhammad Damhuri menggunakan metode diskusi. Sedangkan teknik pengumpulan data dalam penelitian ini adalah studi pustaka dan teknik tes. Teknik Pengolahan Data

Dalam penelitian ini digunakan teknik korelasi product moment dan teknik persentase. Rumus korelasi product moment digunakan untuk mengetahui keefektifan dari penggunaan metode diskusi dalam pembelajaran menentukan unsur tema cerpen Juru Masak karya Muhammad Damhuri. Rumus tersebut adalah sebagai berikut (Rianto, 2018):

$r=\frac{n \cdot \sum x y-\left(\sum x\right)\left(\sum y\right)}{\sqrt{\left\{n \cdot \sum x^{2}-\left(\sum x\right)^{2}\right\}\left(n \sum y^{2}-(\Sigma y)^{2}\right\}}}$

Keterangan.

$r=$ nilai korelasi ( antara variabel $x$ dan $y$ )

$\mathrm{n}=$ jumlah siswa yang diteliti

$\mathrm{x}=$ nilai pretes

$y=$ nilai postes

$\sum \mathrm{x}=$ jumlah nilai pretes

$\sum y=$ jumlah nilai postes

$\sum x y=$ jumlah hasil kali nilai pretes dan postes

$\Sigma \mathrm{x}^{2}=$ jumlah kuadrat nilai pretest

$\sum \mathrm{y}^{2}=$ jumlah kuadrat nilai postes

Adapun skala nilai korelasi $(r)$ antara variabel $(x)$ dan variabel $(y)$ adalah sebagai berikut.

Tabel 1

Interpretasi Nilai Korelasi

\begin{tabular}{ll}
\hline Besarnya nilai korelasi $(\mathbf{r})$ & Interpretasi \\
\hline 0,800 sampai dengan 1,00 & Korelasinya sangat tinggi \\
0,600 sampai dengan 0,800 & Korelasinya tinggi \\
0,400 sampai dengan 0,600 & Korelasinya sedang \\
0,200 sampai dengan 0,400 & Korelasinya kecil
\end{tabular}


Selanjutnya dilakukan teknik prosentase data untuk menggambarkan hasil pretes dan postes kemampuan siswa dalam pembelajaran menentukan tema cerpen dengan metode diskusi. Kriteria yang digunakan dalam teknik prosentase adalah sebagai berikut (Rianto, 2018).

Tabel 2

Interpretasi Nilai Prosentase

\begin{tabular}{ll}
\hline Besarnya Nilai Prosentase & Interprestasi \\
\hline $100 \%$ & Seluruhnya \\
$76 \%-99 \%$ & Hampir seluruhnya \\
$51 \%-75 \%$ & Lebih dari separuh \\
$50 \%$ & Separuhnya \\
$26 \%-49 \%$ & Hampir separuhnya \\
$1 \%-25 \%$ & Sedikit sekali \\
$0 \%$ & Tidak ada satupun \\
\hline
\end{tabular}

\section{Lokasi Penelitian}

Lokasi penelitian adalah tempat melakukan penelitian. Dalam hal ini merupakan nama lembaga atau instansi yang dijadikan tempat penelitian. Lokasi penelitian yang dipilih oleh penulis yaitu di SMA Negeri 1 Maja yang terletak di Desa Maja Selatan Kecamatan Maja Kabupaten Majalengka.

\section{Pembahasan}

\section{Pelaksanaan Metode Diskusi}

Persiapan pengumpulan data merupakan tahap awal proses penelitian. Sesuai dengan tujuan penelitian yang ditetapkan, proses ini dilakukan sebelum melaksanakan penelitian yaitu dengan cara mengumpulkan data-data atau bahan-bahan yang dibutuhkan dalam penelitian. Pada bagian ini penulis akan membahas langkah-langkah persiapan pengumpulan data.

Selanjutnya menyusun Rencana Pelaksanaan Pembelajaran (RPP) yang sesuai dengan subjek penelitian yaitu mengenai pembelajaran mengidentifikasi unsur tema cerpen Juru Masak karya Damhuri Muhammad dengan menggunakan metode diskusi Kelas XI SMA Negeri 1 Maja yang disesuaikan dengan silabus pembelajaran.

Persiapan penyusunan Rencana Pelaksanaan Pembelajaran (RPP) ini penulis lakukan dikarenakan penelitian yang penulis lakukan berkaitan dengan kegiatan pembelajaran. Kegiatan pembelajaran tersebut dilakukan untuk mengetahui kemampuan peserta didik dalam mengidentifikasi unsur tema cerpen Juru Masak karya Damhuri Muhammad di Kelas XI SMA Negeri 1 Maja sebelum dan setelah menggunakan metode diskusi. Melalui dua kegiatan pembelajaran tersebut, data yang ingin penulis kumpulkan yaitu data hasil tes awal (pre tes) dan hasil tes akhir (pos tes).

Rencana Pelaksanaan Pembelajaran (RPP) ini merupakan pedoman atau acuan penulis dalam melaksanakan pembelajaran. Tujuannya yaitu agar pelaksanaan pembelajaran dapat tersusun secara cermat dan jelas. Penyusunan Rencana Pelaksanaan Pembelajaran (RPP) ini mengacu pada Standar Kompetensi dan Kompetensi Dasar (SK dan KD) yang telah ditentukan dalam silabus dan tercantum dalam Kurikulum 2013 (KURTILAS).

Langkah berikutnya adalah tahapan proses pembelajaran dengan menggunakan metode diskusi dalam menentukan unsur tema dalam cerpen Juru Masak karya Damhuri Muhammad penulis jelaskan sebagai berikut. Kegiatan Awal, guru mengucapkan salam, memeriksa daftar hadir peserta didik, memotivasi peserta didik dengan menyampaikan kompetensi dasar dan 


\section{JGI: JURNAL GURU INDONESIA}

2021, 1(1), hlm. $27-33$

https://jurnal.ppjb-sip.org/index.php/jgi/index

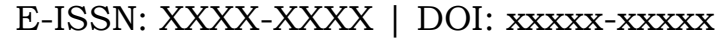

indikator pencapaian pembelajaran, menuliskan topic dan tujuan yang akan dipelajari yaitu pembelajaran menentukan unsur tema cerpen, terakhir menginformasikan model pembelajaran yang akan dilaksanakan yaitu model diskusi .

Kegiatan inti, terdiri dari tiga tahap yaitu eksplorasi. Pada tahap ini Guru membuat dan menyiapkan perlengkapan perangkat pembelajaran. Selanjutnya mengeksplorasi pengetahuan peserta didik melalui pertanyaan-pertanyaan yang berhubungan dengan cerita pendek. Terakhir menyampaikan materi mengenai unsur intrinsik cerita pendek (tema).

Tahap kedua yaitu elaborasi, pada tahap ini guru membagikan buku sebagai media pembelajaran kepada peserta didik, bertanya jawab dengan peserta didik mengenai unsurunsur intrinsik yang terdapat dalam cerpen tersebut. Peserta didik dikelompokkan menjadi lima kelompok (asal) dengan beranggotakan lima sampai enam peserta didik. Setelah itu meminta peserta didik untuk mendengarkan pembacaan cerita pendek melalui siswa yang membacanya. Selanjutnya Setiap kelompok diberikan tugas untuk menentukan unsur tema cerita pendek dan terakhir menyimpulkan hasil diskusinya masing-masing. Tahap ketiga yaitu konfirmasi. Pada tahap ini guru memberikan tugas kepada peserta didik secara individu untuk mengidentifikasi unsur intrinsik cerpen.

\section{Uji Keefektifan}

Tahapan uji keefektifan pada penelitian ini menggunakan tes awal (pretest) dan tes akhir (posttest) kepada peserta didik mengenai pembelajaran mengidentifikasi unsur intrinsic tema cerpen Juru Masak karya Damhuri Muhammad dengan menggunakan metode Diskusi. Adapun data yang diperoleh adalah sebagai berikut.

Data hasil pre tes penulis peroleh pada hari Senin tanggal 19 Mei 2015 dalam pembelajaran menentukan unsur tema cerpen Juru Masak karya Muhammad Damhuri dengan menggunakan metode diskusi. Penelitian ini dilakukan di Kelas XI MIPA 1 SMA Negeri 1 Maja pada jam ketiga dan keempat mata pelajaran Bahasa dan Sastra Indonesia. Jumlah sampel penelitian yang penulis teliti yaitu sebanyak 26 orang peserta didik. Namun pada pelaksanaannya, hanya terdapat 24 orang peserta didik yang mengikuti pre tes dikarenakan dua orang peserta didik sakit.

Pengolahan data hasil tes awal (pre tes) menunjukkan kemampuan peserta didik dalam dalam menentukan unsur intrinsik tema cerpen Juru Masak karya Muhammad Damhuri di Kelas XI SMA Negeri 1 Maja sebelum pembelajaran menggunakan metode diskusi. Pengolahan data pre tes lebih jelasnya penulis gambarkan sebagai berikut.

Pertama, nilai rata-rata pre tes adalah sebesar 71 atau $71 \%$ artinya kemampuan dalam menentukan unsur intrinsik tema cerpen Juru Masak karya Muhammad Damhuri sebelum pembelajaran menggunakan metode diskusi menunjukkan kriteria sudah separuhnya peserta didik dapat mengidentifikasi unsur tema cerpen hanya masih dibawah KKM. Kedua, nilai terendah pre tes adalah 60 atau $60 \%$ artinya kemampuan dalam menentukan unsur intrinsik tema cerpen Juru Masak karya Muhammad Damhuri sebelum pembelajaran menggunakan metode diskusi menunjukkan separuhnya peserta didik tersebut belum dapat mengidentifikasi unsur tema cerpen dengan tepat. Ketiga, tertinggi pre tes adalah 80 atau $80 \%$ artinya kemampuan dalam menentukan unsur intrinsik tema cerpen Juru Masak karya Muhammad Damhuri sebelum pembelajaran menggunakan metode diskusi menunjukkan sebagian kecil peserta didik tersebut dapat mengidentifikasi unsur tema cerpen dengan tepat.

Tahap berikutnya yaitu melakukan pos tes. Data hasil pos tes penulis peroleh pada hari Selasa tanggal 19 Mei 2015 dalam dalam menentukan unsur intrinsik tema cerpen Juru Masak karya Muhammad Damhuri. Penelitian ini dilakukan di Kelas XI MIPA 1 SMA Negeri 1 Maja pada jam ketiga 
dan keempat mata pelajaran Bahasa dan Sastra Indonesia. Jumlah sampel penelitian yang penulis teliti yaitu sebanyak 26 orang peserta didik. Namun kenyataannya, hanya terdapat 24 orang peserta didik yang mengikuti pos tes dikarenakan dua orang peserta didik sakit.

Data hasil pos tes diperlukan untuk menjawab rumusan masalah yang kedua yaitu bagaimana kemampuan peserta didik menentukan unsur intrinsik tema cerpen Juru Masak karya Muhammad Damhuri di Kelas XI SMA Negeri 1 Maja Tahun Ajar 2014/2015 setelah pembelajaran dengan menggunakan metode diskusi. Pengolahan data hasil tes akhir (pos tes) di atas menunjukkan kemampuan peserta didik dalam menentukan unsur intrinsik tema cerpen Juru Masak karya Muhammad Damhuri di Kelas XI SMA Negeri 1 Maja Tahun Ajar 2014/2015 setelah pembelajaran menggunakan metode diskusi. Pengolahan data pos tes lebih jelasnya penulis gambarkan sebagai berikut.

Pertama, nilai rata-rata pos tes adalah sebesar 79,2 atau $79,2 \%$ artinya kemampuan menentukan unsur intrinsik tema cerpen Juru Masak karya Muhammad Damhuri setelah pembelajaran dengan menggunakan metode diskusi menunjukkan kriteria hampir seluruhnya peserta didik dapat mengidentifikasi unsur tema cerpen dengan tepat. Kedua, nilai terendah pos tes adalah 70 atau $70 \%$ artinya kemampuan menentukan unsur intrinsik tema cerpen Juru Masak karya Muhammad Damhuri setelah pembelajaran menggunakan metode diskusi menunjukan kriteria lebih dari nilai terendah pre tes sebelumnya yaitu 2,4 , artinya ada peningkatan dalam mengidentifikasi unsur tema cerpen setelah menggunakan metode diskusi. Ketiga, nilai tertinggi pos tes adalah 90 atau $90 \%$ artinya kemampuan menentukan unsur intrinsik tema cerpen Juru Masak karya Muhammad Damhuri melalui pembelajaran menggunakan metode diskusi menunjukkan kriteria hampir seluruhnya peserta didik tersebut dapat mengidentifikasi unsur tema cerpen dengan tepat.

Tahap terakhir uji validitas adalah penghitungan menggunakan rumus korelasi product moment Berdasarkan penghitungan menggunakan rumus korelasi product moment di atas diperoleh $r=0,760$. Dengan demikian metode diskusi efektif digunakan dalam pembelajaran menentukan unsur intrinsik tema cerpen Juru Masak karya Muhammad Damhuri di Kelas XI SMA Negeri 1 Maja Tahun Ajar 2013/2014. Sementara itu, nilai korelasi yang diperoleh menunjukkan nilai korelasi yang tinggi.

\section{Simpulan}

Simpulan yang penulis peroleh dari pengolahan data dan pembahasan hasil penelitian mengenai pembelajaran menentukan unsur tema cerpen Juru Masak karya Damhuri Muhammad dengan menggunakan metode diskusi di Kelas XI SMA Negeri 1 Maja adalah berdasarkan hasil penghitungan dengan menggunakan rumus korelasi product moment antara nilai rata-rata pretest dan nilai rata-rata posttest menunjukkan nilai korelasi sebesar 0,760 atau berdasarkan pedoman pemberian interpretasi koefisien korelasi data menunjukkan korelasi yang tinggi.

\section{Daftar pustaka}

Made, N., Sari, P., \& Nyoman, I. (2013). Buzz Group Pada Siswa Kelas Viii a Smp Dwijendra Gianyar Tahun Pelajaran 2011 / 2012 Jurnal Santiaji Pendidikan, 3(2), 150-162.

Rianto. (2018). Efektivitas Penggunaan Metode Sugesti-Imajinasi Melalui Media Audio-Visual dalam Pembelajaran Menulis Cerpen Di SMA Kelas X. Jurnal Pendidikan, 1(1), 64-85.

Saman, S., Ramdani, D., \& Intrinsik, U. (2015). Unsur-Unsur Intrinsik Cerpen Melalui Metode. Jurnal Pendidikan dan Pembelajaran Khatulistiwa. 4(3). 1-13.

Sanjaya, W. (2008). "Strategi Pembelajaran Berorientasi Standar Proses Pendidikan". Jakarta: Kencana Prenada Media Group.

Sudjana \& Ibrahim. (2001). "Penelitian dan Penilaian Pendidikan". Bandung: Sinar Baru Algensindo. 


\section{JGI: JURNAL GURU INDONESIA}

2021, 1(1), hlm. $27-33$

https://jurnal.ppjb-sip.org/index.php/igi/index

E-ISSN: XXXX-XXXX | DOI: $\mathrm{xxxxx-xxxxx}$

Sugiyono. (2010). "Metode Penelitian Administrasi Dilengkapi dengan Metode R\&D". Bandung: CV Alfabeta.

Sumiati \& Arsa. (2011). "Metode Pembelajaran". Bandung: Wacana Prima. 